\title{
The Mitigation of Landslide Disaster at the Area that Formerly a Soil and Rock Mining in Bukit Permai Singkawang
}

\author{
Marsudi $^{1,4 *}$, Budi Purwoko ${ }^{1,4}$, Singgih Saptono ${ }^{2,4}$, Nurmaya Putri Ira ${ }^{2,4 *}$, Fahrul Indrajaya ${ }^{3,4}$ \\ ${ }^{1}$ Universitas Tanjungpura \\ ${ }^{2}$ Universitas Pembangunan Nasional "Veteran” Yogyakarta \\ ${ }^{3}$ Universitas Palangka Raya \\ ${ }^{4}$ Universities Consortium for Open Mining Methods, Indonesia
}

*Corresponding Author: Nurmaya Putri Ira, Universitas Pembangunan Nasional "Veteran” Yogyakarta, Universities Consortium for Open Mining Methods, Indonesia

\begin{abstract}
Earth movement or landslide is one of the most frequently geological natural disasters happening in many places in Indonesia. From topology point of view, the landslide occurs on the slope of more than 35 degree and comprises of weathered soil in particular, is very dangerous to the nearby infrastructures.

Generally, the research method employed to mitigate and to detect earth movement is geoelectrical (resistivity) survey. This technique is applied to understand the condition or the geology structure under the surface based on the variation on the specific resistance or resistivity of the rocks. This method in particular could distinguish the geology structures that are significantly different or contrast in their resistivity from their surrounding areas. In addition to identify the area which likely to have landslide, the technique could also be used to explore ground water, minerals, and geothermal potency.

The geophysics evidence observed on the slope landslide occurred several years ago. The downhill was cut to obtain the soil and rock materials for the land fill purpose. The hill was cut up to $\pm 22 \mathrm{~m}$ above sea level, with the thickness of $10 \mathrm{~m}$ to $15 \mathrm{~m}$. And this obviously resulted in the loss in support capability at the downhill. The landslide then occurred from the bottom side of the hill to the uphill at 108 above sea level. Prior to the occurrence, the cracks and fragmented materials were observed in various points, from $22 \mathrm{~m}$ to $108 \mathrm{~m}$ above sea level. The crack dimensions were varied from $10 \mathrm{~cm}$ to $50 \mathrm{~cm}$, in the length of $1 \mathrm{~m}$ to $20 \mathrm{~m}$, transverse perpendicular to the slope of the hill.
\end{abstract}

Keywords: Disasters, Infrastructure, Geoelectrical, landslide, slope stability and Mitigation

\section{INTRODUCTION}

From geology point of view, landslide is usually happening due to the natural movement of soil materials at the slope or hilly area. This cyclical occurrence of this natural disaster is not uncommon, from monthly period up to decades, usually during raining season.

Almost all of geology catastrophes, such as earthquake, tsunami, volcano eruption, and other tectonic movements, are purely natural disaster due to geology process, which unfortunately are impossible to prevent and very difficult to predict. Intensive research works in geology fields in particular, should be carried out to mitigate these natural disasters.

On the other hand, natural disasters like landslide, land subsidence, and flooding are not only caused by prone and unstable geological conditions, but in many cases also due to human activities, particularly in intensifying land exploitation. In addition, climate change also contributes significantly to escalating the number of landslides in many places in Indonesia.

Fundamentally, like many other natural phenomena, landslide is happening when the driving force works on the slope is greater than the resistance force. The main factors affecting the driving force are the angle of the slope, the quantity of water flowing, the load and the densities of soil and rock, specifically when unconsolidated soil is exist in a great quantity. The resistance force is determined by the strength of the rock as well as the solidity of soil. 
Therefore, the identified factors that are causing landslide are including rain intensity, steep slope, thickness of unconsolidated soil, weak soil/rock, mining activities of rocks and soil at the bottom of the cliff, improper land use, vibration caused by earthquake, drop in water level, additional load due to rainwater absorption, erosion, unconsolidated pile of material on the cliff, present of discontinue field, deforestation, and unstable or unconsolidated pile of waste disposal.

During landslide, the downward movement of mass soil is due to the gravity force and the higher soil surface tension than soil friction strength. This soil mass then damaging the lower side area, destroy infrastructures such as property, housing, warehouse, etc. The outcomes are not only physical damages on the infrastructures, but also life casualties. These backgrounds lead to the following objectives of this paper, which includes:

- To understand the landslide mechanism, which then can be used to mitigate this geology disaster, in order to protect the infrastructures in the area where the study has been carried out.

- To apply geoelectric survey in order to obtain the analyses on landslide field.

\section{RESEARCH METHOD}

In order to mitigate landslide disaster, the geoelectric prediction method employed in this study was resistivity imaging technique. This technique was to obtain data on landslide fields during the landslide event in the area that was formerly a soil and rock mining. This area, Bukit Permai, is now utilized as water treatment plant and water reservoir as well.

Geoelectric prediction had been done in three different paths as can be seen in Figure 1. Based on geology classification, the compositions of the rock type in the area are: as follow.

- Laterite soil (weathering soil) with the thickness of 6 to $13.9 \mathrm{~m}$, that is soft and weak.

- Half weathered rock in the form of frozen rock chunk with the thickness between 2 to $4 \mathrm{~m}$. This is compact and relatively hard rock.

- At the bottom, there is fresh rock (grano-diorite rock). This kind of rock is massif, strong, and hard.

Geoelectric measurement used Wenner - Alpha configuration with the span length of 75 to $100 \mathrm{~m}$, to acquire the prediction of 25 to $50 \mathrm{~m}$ in depth.

\subsection{Location}

Figure 1 shows Bukit Permai Water Treatment Plant area, in which the study was conducted. The three different prediction point paths were made parallel with the slope, as can be seen in Figure 2.1. The paths/tracks are Path $1(\mathrm{~A}-\mathrm{B})$, Path $2(\mathrm{C}-\mathrm{D})$, and Path $3(\mathrm{E}-\mathrm{F})$. These are to predict or do detect the thickness of soil/rock layers under the geoelectric prediction points.

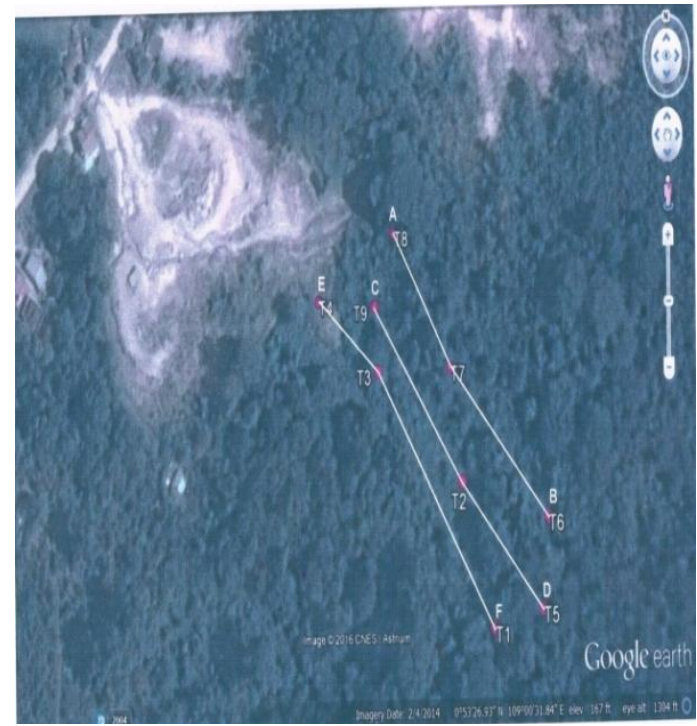

Figure2.1. The map of Bukit Permai Water Treatment Plant area with geoelectric prediction path 


\subsection{Basic Theory}

The research study shall be conducted systematically, which are including preparation stage, field data collecting, data processing, evaluation, and report presentation. And all of those steps shall be in accordance with scientific standard. During this study several basic theory are used as follow.

\subsubsection{Resistivity}

When DC current applied on certain medium, the ratio between electric potential (V) and quantity of the current (I) is constant. And the quantity of this constant number depends on the medium, which called resistance $(\mathrm{R})$. Therefore the resistance $(\mathrm{R})$ can be expressed as below:

$$
R=\frac{V}{I}(\mathrm{Ohm})
$$

And when the electric current applied on wire or homogeneous cylinder through its axis, the resistance $\mathrm{R}$ will directly proportion to the cylinder length (L) and inversely proportional to cylinder cross-sectional area (A). If $\rho$ is a constant ratio called resistivity in the unit of Ohm.m, thus from above equation it can derived the following equation:

$$
\begin{aligned}
& \rho=\frac{A V}{L I}(\text { Ohm.m }) \\
& R \approx \frac{L}{A}(\text { Ohm.m })
\end{aligned}
$$

\subsubsection{Electrode Configuration}

The measurement of geoelectric resistivity during this aquifer mapping work employedSchlumberger method. Electrode arrangement according to Schlumberger principle is basically consist of two current electrodes and potential electrodes, as can be seen in Figure 2.2. below.

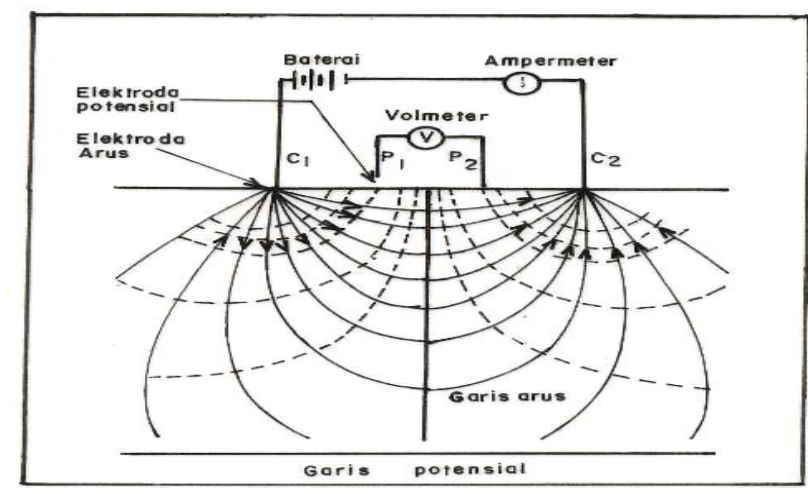

Figure2.2. Two current electrode and two potential electrode on earth surface

The potential in $\mathrm{P} 1$ that is caused by $\mathrm{C} 1$ is:

$$
V_{1}=-\frac{I \rho}{2 \pi r_{1}}
$$

Since the current is the same but different in pole, thus the potential in P2 caused by current in $\mathrm{C} 2$ is :

$$
V_{2}=+\frac{I \rho}{2 \pi r_{2}}
$$

It is expected that the measurement not depend on touch resistance on current electrode A and B. Wenner (1917) and C \& M Schlumberger (1920) proposed the technique which called Schlumberger configuration. In this technique, electrode $\mathrm{A}$ and electrode $\mathrm{B}$ are placed in symmetric against the centre point and then adding potential electrodes $\mathrm{M}$ and $\mathrm{N}$, which are also positioned symmetric against the centre point, between electrode A and B. The schematic figure of Schlumberger configuration is presented in Figure 2.3. 


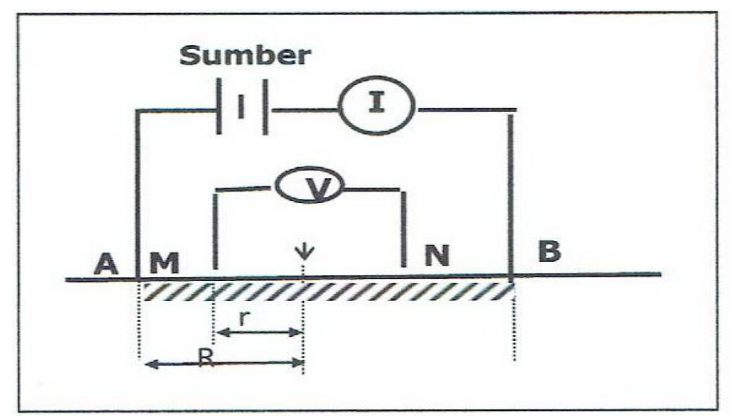

Figure2.3. The arrangement of Schlumberger Electrode

If $\begin{array}{lll}\mathrm{R} & = & \mathrm{AB} / 2 \\ \mathrm{r} & = & \mathrm{MN} / 2\end{array}$

Thus the geometri factor of Schlumberger configuration is:

$$
\begin{aligned}
& K=\frac{2 \pi}{\left[\left(\frac{1}{A M}-\frac{1}{B M}\right)-\left(\frac{1}{A N}-\frac{1}{B N}\right)\right]} \\
& K=\frac{2 \pi}{\left[\left(\frac{1}{R-r}-\frac{1}{R+r}\right)-\left(\frac{1}{R+r}-\frac{1}{R-r}\right)\right]}=\frac{2}{\frac{2}{R r} \frac{2}{R+r} \div}=\frac{2}{\frac{4 r}{R r} \div} \\
& K=\frac{\pi\left(R^{2}-r^{2}\right)}{r^{2}}=\frac{\pi\left[\left(\frac{A B}{2}\right)^{2}-\left(\frac{M N}{2}\right)^{2}\right]}{2\left(\frac{M N}{2}\right)}
\end{aligned}
$$

$\mathrm{K}$ is a geometri factor in meter unit. It is obvious that geometri factor depends on the position of current electrode as well as potential electrode. In this technique, the distance between potential electrodes is seldom to change eventhough the space between current electrodes are always altered. During the change in electrode spatial distance, the current electrode distance must be significantly greater than the potential electrode distance. The optimum space of $\mathrm{AB} / 2$ must be larger than $5 \mathrm{MN} / 2$.

\subsection{Data Interpretation}

\section{A. Path A - B}

Path A-B situated at the eastern part (right hand side), and the result of geoelectric prediction is presented in profile A-B as can be seen in Figure 2.4.

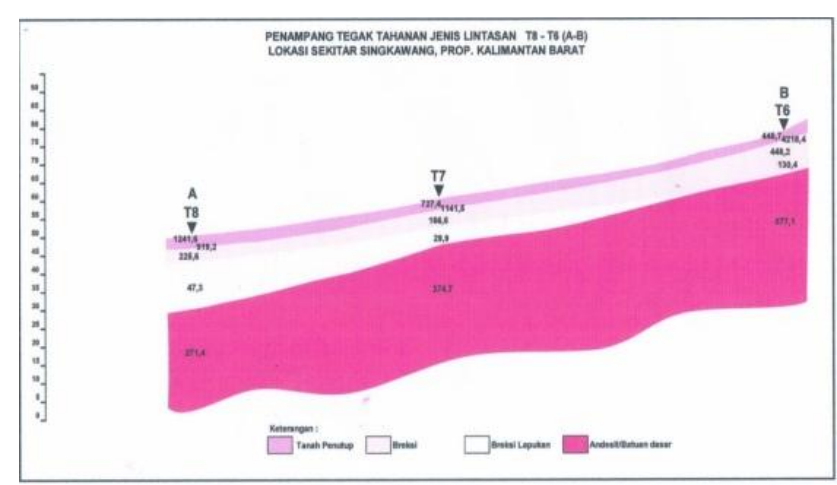

Figure2.4. Soil profile resulted from geoelectric prediction on $A-B$

\section{B. Path C - D}

Path C-D positioned right at the center, and the result of geoelectric prediction is presented in profile C-D as can be seen in Figure 2.5. 
The Mitigation of Landslide Disaster at the Area that Formerly a Soil and Rock Mining in Bukit Permai Singkawang

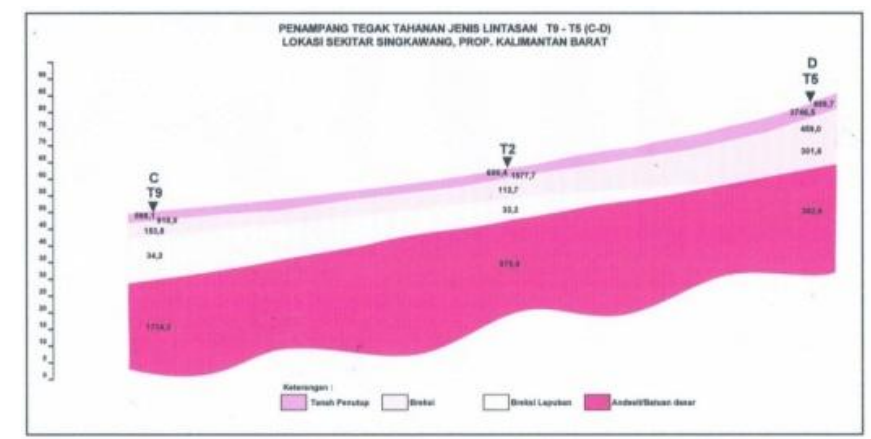

Figure2.5. Soil profile resulted from geoelectric prediction on Path $C-D$

\section{Path E - F}

Path E-F located at the western part (left hand side), and the result of geoelectric prediction is presented in profile E-F as can be seen in Figure 2.6.

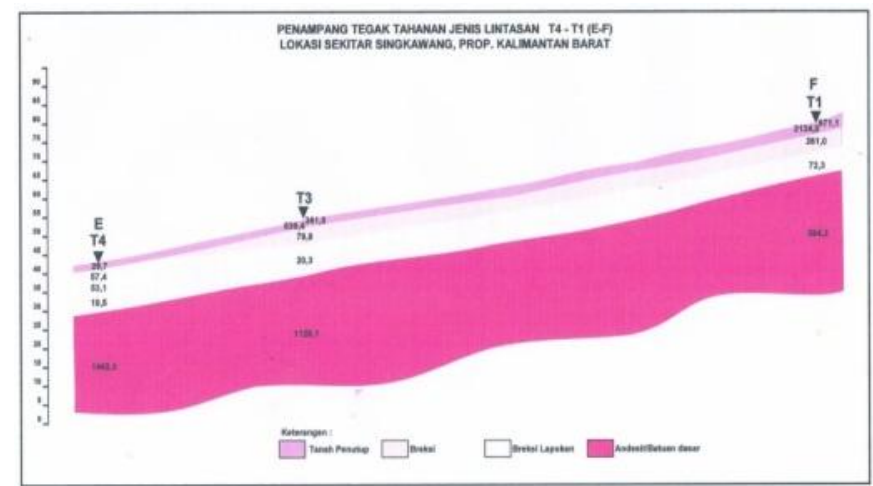

Figure2.6. Soil profile resulted from geoelectric prediction on Path $E-F$

The result on resistivity obtained from geoelectric prediction is then presented in Table 1 below.

Tabel1. Interpretation Result Data Measurement Geoelectrical Prisoner Type in Location Singkawang

\begin{tabular}{|c|c|c|c|c|c|c|c|c|c|c|c|c|c|c|c|c|c|c|}
\hline \multirow{2}{*}{$\begin{array}{l}\mathbf{N} \\
\mathbf{0}\end{array}$} & \multirow{2}{*}{$\begin{array}{c}\text { Loc } \\
\text { atio } \\
\text { n } \\
\text { cod } \\
\text { e }\end{array}$} & \multirow{2}{*}{\multicolumn{2}{|c|}{ Coordinate }} & \multirow{2}{*}{$\begin{array}{l}\text { Height( } \\
\text { meters) }\end{array}$} & \multicolumn{5}{|c|}{$\begin{array}{l}\text { Layer type resistance } \\
\text { (ohm.m) }\end{array}$} & \multicolumn{4}{|c|}{ Thickness (m) } & \multicolumn{5}{|c|}{ Depth (m) } \\
\hline & & & & & $\begin{array}{l}\text { p- } \\
1\end{array}$ & p-2 & $\begin{array}{c}\text { p- } \\
3\end{array}$ & $\begin{array}{l}\text { p- } \\
4\end{array}$ & p-5 & $\begin{array}{l}t \\
1\end{array}$ & 2 & t3 & t4 & $\begin{array}{l}d \\
1\end{array}$ & $\begin{array}{l}\text { d } \\
2\end{array}$ & $\begin{array}{l}\mathbf{d} \\
\mathbf{3}\end{array}$ & $\begin{array}{l}d \\
4\end{array}$ & $\begin{array}{l}\text { d } \\
5\end{array}$ \\
\hline 1 & $\mathrm{~T}-1$ & $\begin{array}{c}0^{\circ} 53 ' 2 \\
4.32^{\prime \prime} \\
\mathrm{N}\end{array}$ & $\begin{array}{l}109^{\circ} 0^{\prime} 3 \\
4.23^{\prime \prime} \mathrm{E}\end{array}$ & 79 & $\begin{array}{l}97 \\
1,1\end{array}$ & $\begin{array}{c}213 \\
4,0\end{array}$ & $\begin{array}{c}26 \\
1, \\
0\end{array}$ & $\begin{array}{l}72 \\
, 3\end{array}$ & $\begin{array}{c}394, \\
2\end{array}$ & $\begin{array}{l}1 \\
2\end{array}$ & 4 & $\begin{array}{c}6 \\
1\end{array}$ & $\begin{array}{l}6, \\
3\end{array}$ & $\begin{array}{l}0 \\
0\end{array}$ & $\begin{array}{l}1 \\
2\end{array}$ & $\begin{array}{l}3 \\
6 \\
6\end{array}$ & $\begin{array}{l}9 \\
7\end{array}$ & 0 \\
\hline 2 & $\mathrm{~T}-2$ & $\begin{array}{c}0^{\circ} 53^{\prime} 2 \\
5.73^{\prime \prime} \\
\mathrm{N}\end{array}$ & $\begin{array}{l}109^{\circ} 0^{\prime} 3 \\
3.75^{\prime \prime} \mathrm{E}\end{array}$ & 68 & $\begin{array}{l}60 \\
0,4\end{array}$ & $\begin{array}{l}157 \\
7,7\end{array}$ & $\begin{array}{l}11 \\
2, \\
7\end{array}$ & $\begin{array}{r}32 \\
, 2\end{array}$ & $\begin{array}{c}979 \\
9\end{array}$ & $\begin{array}{l}1 \\
\text {, }\end{array}$ & 0 & $\begin{array}{l}6 \\
2\end{array}$ & $\begin{array}{l}7, \\
9\end{array}$ & $\begin{array}{l}0 \\
0\end{array}$ & $\begin{array}{l}1 \\
0\end{array}$ & $\begin{array}{l}1 \\
8 \\
8\end{array}$ & $\begin{array}{c}8, \\
0\end{array}$ & 9 \\
\hline 3 & $\mathrm{~T}-3$ & $\begin{array}{c}0^{\circ} 53^{\prime} 2 \\
6.88^{\prime \prime} \\
\mathrm{N}\end{array}$ & $\begin{array}{l}109^{\circ} 0^{\prime} 3 \\
2.28^{\prime \prime} \mathrm{E}\end{array}$ & 54 & $\begin{array}{l}36 \\
1,5\end{array}$ & $\begin{array}{c}539 \\
4\end{array}$ & $\begin{array}{r}79 \\
, 8\end{array}$ & $\begin{array}{l}20 \\
, 3\end{array}$ & $\begin{array}{c}112 \\
6,1\end{array}$ & $\begin{array}{l}0 \\
9\end{array}$ & 0 & $\begin{array}{l}5 \\
9\end{array}$ & $\begin{array}{c}8, \\
1\end{array}$ & $\begin{array}{l}0 \\
0\end{array}$ & $\begin{array}{l}0 \\
9\end{array}$ & $\begin{array}{l}1 \\
6\end{array}$ & $\begin{array}{l}7 \\
5\end{array}$ & 1 \\
\hline 4 & $\mathrm{~T}-4$ & $\begin{array}{c}0^{\circ} 53^{\prime} 2 \\
7.66^{\prime \prime} \\
\mathrm{N}\end{array}$ & $\begin{array}{l}109^{\circ} 0^{\prime} 3 \\
1.16^{\prime \prime} \mathrm{E}\end{array}$ & 43 & $\begin{array}{c}29 \\
7\end{array}$ & 57,4 & $\begin{array}{c}53 \\
, 1\end{array}$ & $\begin{array}{r}19 \\
, 5\end{array}$ & $\begin{array}{l}144 \\
2,3\end{array}$ & $\begin{array}{l}0 \\
8 \\
\end{array}$ & 0 & $\begin{array}{l}4, \\
2\end{array}$ & $\begin{array}{l}6 \\
4\end{array}$ & $\begin{array}{l}0 \\
0 \\
0\end{array}$ & $\begin{array}{l}0 \\
8\end{array}$ & $\begin{array}{l}1 \\
, \\
5\end{array}$ & $\begin{array}{l}5, \\
7\end{array}$ & 1 \\
\hline 5 & $\mathrm{~T}-5$ & $\begin{array}{c}0^{\circ} 53^{\prime} 2 \\
4.52^{\prime \prime} \\
\mathrm{N}\end{array}$ & $\begin{array}{c}109^{\circ} 0^{\prime} 3 \\
5.05^{\prime \prime} \mathrm{E}\end{array}$ & 82 & $\begin{array}{l}89 \\
9,7\end{array}$ & $\begin{array}{c}374 \\
6,5\end{array}$ & $\begin{array}{c}45 \\
9, \\
0\end{array}$ & $\begin{array}{l}20 \\
1, \\
6\end{array}$ & $\begin{array}{c}382, \\
6\end{array}$ & $\begin{array}{l}1 \\
0\end{array}$ & 1 & $\begin{array}{c}9, \\
0\end{array}$ & $\begin{array}{c}9, \\
0\end{array}$ & $\begin{array}{l}0 \\
0\end{array}$ & $\begin{array}{l}1 \\
0\end{array}$ & $\begin{array}{l}2 \\
, \\
1\end{array}$ & $\begin{array}{l}1 \\
1, \\
1\end{array}$ & 1 \\
\hline 6 & $\mathrm{~T}-6$ & $\begin{array}{c}0^{\circ} 53^{\prime} 2 \\
5.39^{\prime \prime} \\
\mathrm{N}\end{array}$ & $\begin{array}{c}109^{\circ} 0^{\prime} 3 \\
5.20^{\prime \prime} \mathrm{E}\end{array}$ & 78 & $\begin{array}{l}44 \\
5,7\end{array}$ & $\begin{array}{l}421 \\
8,4\end{array}$ & $\begin{array}{l}48 \\
8, \\
2\end{array}$ & $\begin{array}{l}13 \\
0, \\
4\end{array}$ & $\begin{array}{c}877, \\
1\end{array}$ & $\begin{array}{l}1 \\
0\end{array}$ & 1 & $\begin{array}{l}3, \\
9\end{array}$ & $\begin{array}{l}8 \\
4\end{array}$ & $\begin{array}{l}0 \\
0\end{array}$ & $\begin{array}{l}1 \\
0\end{array}$ & $\begin{array}{l}2 \\
2 \\
2\end{array}$ & $\begin{array}{l}6, \\
1\end{array}$ & 5 \\
\hline 7 & $\mathrm{~T}-7$ & $\begin{array}{c}0^{\circ} 53^{\prime} 2 \\
6.89^{\prime \prime} \\
\mathrm{N}\end{array}$ & $\begin{array}{c}109^{\circ} 0^{\prime} 3 \\
3.60^{\prime \prime} \mathrm{E}\end{array}$ & 61 & $\begin{array}{l}72 \\
7,4\end{array}$ & $\begin{array}{l}114 \\
1,5\end{array}$ & $\begin{array}{c}16 \\
6, \\
6\end{array}$ & $\begin{array}{r}29 \\
, 9\end{array}$ & $\begin{array}{c}347 \\
7\end{array}$ & $\begin{array}{l}1 \\
\text {, } \\
1\end{array}$ & 1 & $\begin{array}{l}3, \\
5\end{array}$ & $\begin{array}{l}8, \\
8\end{array}$ & $\begin{array}{l}0 \\
0 \\
0\end{array}$ & $\begin{array}{l}1 \\
\text {, } \\
1\end{array}$ & $\begin{array}{l}2 \\
5 \\
5\end{array}$ & $\begin{array}{l}6, \\
0\end{array}$ & 8 \\
\hline 8 & $\mathrm{~T}-8$ & $\begin{array}{c}0^{\circ} 53^{\prime} 2 \\
8.36^{\prime \prime} \\
\mathrm{N}\end{array}$ & $\begin{array}{l}109^{\circ} 0^{\prime} 3 \\
2.62^{\prime \prime} \mathrm{E}\end{array}$ & 48 & $\begin{array}{c}12 \\
41, \\
6\end{array}$ & $\begin{array}{c}919, \\
2\end{array}$ & $\begin{array}{c}22 \\
5, \\
6\end{array}$ & $\begin{array}{l}47 \\
, 3\end{array}$ & $\begin{array}{c}271 \\
4\end{array}$ & $\begin{array}{l}1 \\
3\end{array}$ & 1 & $\begin{array}{l}4, \\
8\end{array}$ & $\begin{array}{c}1 \\
3, \\
9\end{array}$ & $\begin{array}{l}0 \\
0\end{array}$ & $\begin{array}{l}1 \\
3\end{array}$ & $\begin{array}{l}3 \\
0 \\
0\end{array}$ & $\begin{array}{l}7, \\
8\end{array}$ & 2 \\
\hline 9 & $\mathrm{~T}-9$ & $\begin{array}{c}0^{\circ} 53^{\prime} 2 \\
7.57^{\prime \prime} \\
\mathrm{N}\end{array}$ & $\begin{array}{l}109^{\circ} 0^{\prime} 3 \\
2.23^{\prime \prime} \mathrm{E}\end{array}$ & 50 & $\begin{array}{l}59 \\
8,1\end{array}$ & $\begin{array}{c}918, \\
0\end{array}$ & $\begin{array}{l}15 \\
3, \\
8\end{array}$ & $\begin{array}{l}34 \\
, 2\end{array}$ & $\begin{array}{l}171 \\
4,3\end{array}$ & $\begin{array}{l}0 \\
9 \\
9\end{array}$ & 1 & $\begin{array}{c}4, \\
1\end{array}$ & $\begin{array}{l}1 \\
3, \\
4\end{array}$ & $\begin{array}{l}0 \\
0 \\
\end{array}$ & $\begin{array}{l}0 \\
9 \\
\end{array}$ & $\begin{array}{l}1 \\
9 \\
9\end{array}$ & $\begin{array}{l}6, \\
0\end{array}$ & 1 \\
\hline
\end{tabular}


The Mitigation of Landslide Disaster at the Area that Formerly a Soil and Rock Mining in Bukit Permai Singkawang

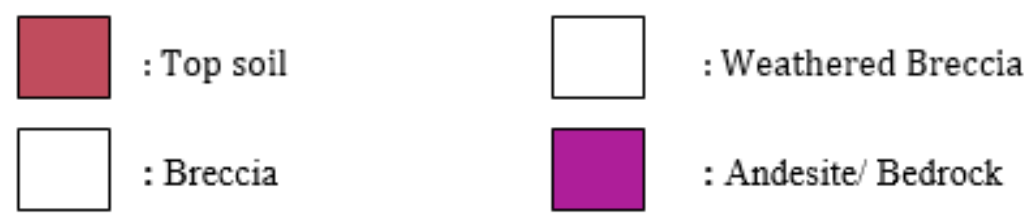

\section{Results}

The landslide potential is described as zone $\Delta$ with the broken line as can be seen in Figure 2.7.

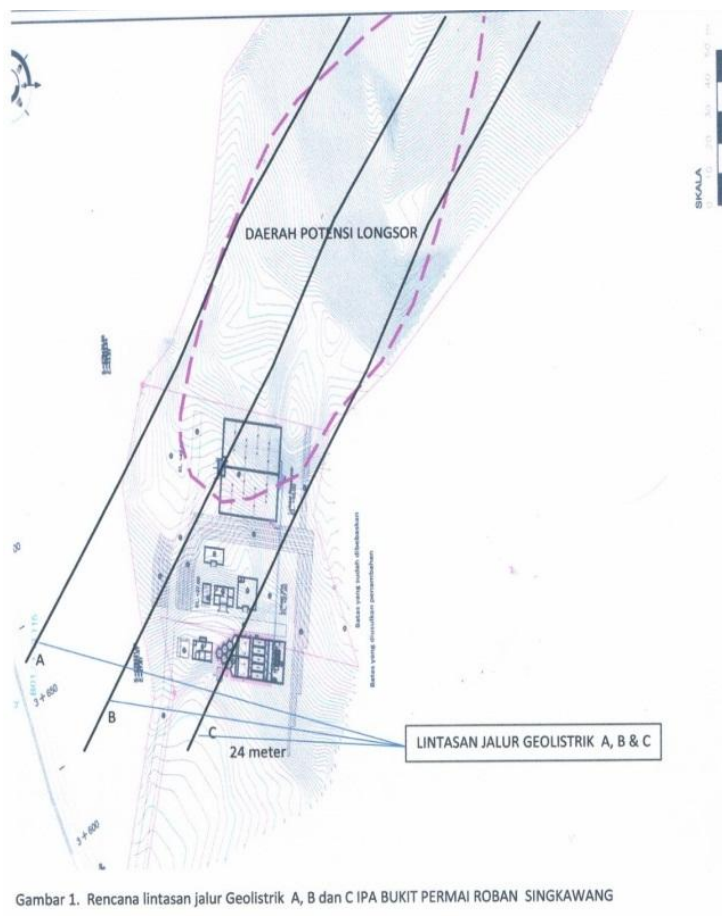

Figure2.7. The distribution of Block $A$ and $B$, and the cut \& fill area, and zone dangerous zone on the upper side.

In Figure 2.8. below, the $2 \mathrm{D}$ cross section of geoelectric path $\mathrm{C}-\mathrm{D}$ is shown to represent the landslide field.

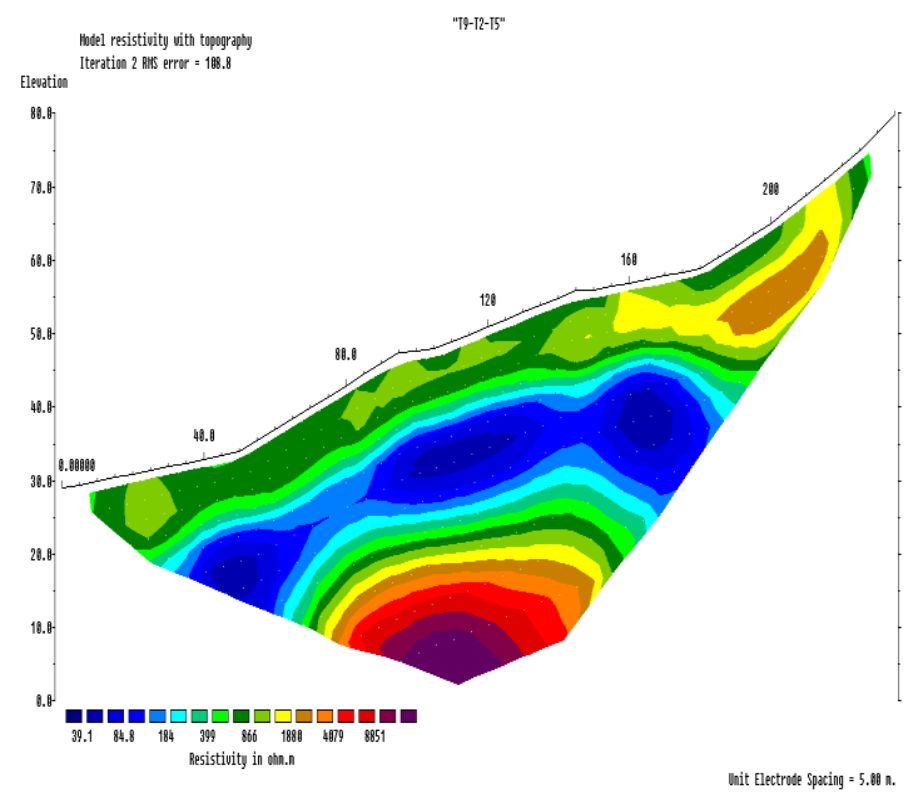

Figure2.8. The $2 D$ cross section of geoelectric path $C-D$ to show the landslide field 
The Mitigation of Landslide Disaster at the Area that Formerly a Soil and Rock Mining in Bukit Permai Singkawang

\subsection{Slope Stability Analysis}

The Basic Principle of the Fellenius Method in general the collapse is assumed to result from the movement of the ground block on a circular or circularly shaped surface of the sphere. On an analyzed slope which divides it in $\mathrm{n}$ segments / slices, there will be (5n-2) variables that are not known, while there are only $3 n$ pieces of static equations are:

- Normal force balance equations

- Tangential equilibrium equation

- Moment balance equation

To be able to solve the problem on a. In general there are three things that can be made, namely:

1. Assumptions about the normal stress distribution along the slip plane

2. Assumptions about the inclination of inter-slice forces

3. Assumptions about the position of the thrust line of inter-slice forces

In table below, the Fellenius Method Analysis is tabulated.

Tabel2. Analysis with Fellinius Method

\begin{tabular}{|c|c|c|c|c|c|c|}
\hline $\begin{array}{c}\text { Slice } \\
\text { Number }\end{array}$ & $\begin{array}{c}\text { Weight } \\
\left(\mathrm{W}_{\mathrm{i}}\right)(\text { ton })\end{array}$ & $(\theta)^{\circ}$ & $\begin{array}{c}\mathrm{W}_{\mathrm{i}} \cos \theta_{i} \\
(\text { ton })\end{array}$ & $\begin{array}{c}\mathrm{W}_{\mathrm{i}} \sin \theta_{i} \\
(\text { ton })\end{array}$ & $\begin{array}{c}\mathrm{U}_{\mathrm{i}}=\mathrm{u}_{\mathrm{i}} \cdot \mathrm{a}_{\mathrm{i}} \\
(\text { ton })\end{array}$ & $\begin{array}{c}\mathrm{W} \cos \theta_{i}- \\
\mathrm{U}_{\mathrm{i}} \\
\text { (ton) }\end{array}$ \\
\hline 1 & 2079 & 1,5 & 2078 & 54,4 & 1980 & 98 \\
\hline 2 & 4158 & 2,2 & 4155 & 160 & 3300 & 854,47 \\
\hline 3 & 5544 & 3,4 & 5534 & 329 & 4620 & 913 \\
\hline 4 & 8349 & 10 & 8222 & 1450 & 5940 & 2215 \\
\hline 5 & 9702 & 15 & 9371 & 2511 & 6710 & 2668 \\
\hline 6 & 8140 & 22 & 7547 & 3049 & 4520 & 2916 \\
\hline 7 & 5544 & 28 & 4595 & 2603 & 3410 & 1375 \\
\hline 8 & 4158 & 35 & 3582 & 2385 & 1980 & 1265 \\
\hline 9 & 2002 & 42 & 1488 & 1340 & 880 & 605 \\
\hline 10 & 660 & 48 & 401 & 445 & 440 & 18,7 \\
\hline & & & 18101 & & 13017,40 \\
\hline
\end{tabular}

Where:

$\mathrm{SF}=\frac{c L+\tan \emptyset \sum W i \operatorname{Cos} \alpha i-U i l i}{\sum(W i \operatorname{Sin} \alpha i}$

Landslide resistance $=\sum c i . a i=1,8 \times 120=216$ ton

$\operatorname{Tan} 48^{\circ}$ x $13017,4=14490$

Safety number in Bukit Permai cliff therefore is:

$\mathrm{SF}=\frac{216+14490}{18101}=0,81<1$

Which is not safe.

In Figure 3.1. below, the slope in Water Treatment Plant and water reservoir of 150 LPD (Liter Per Day) in Bikat Permai - Roban is presented. 


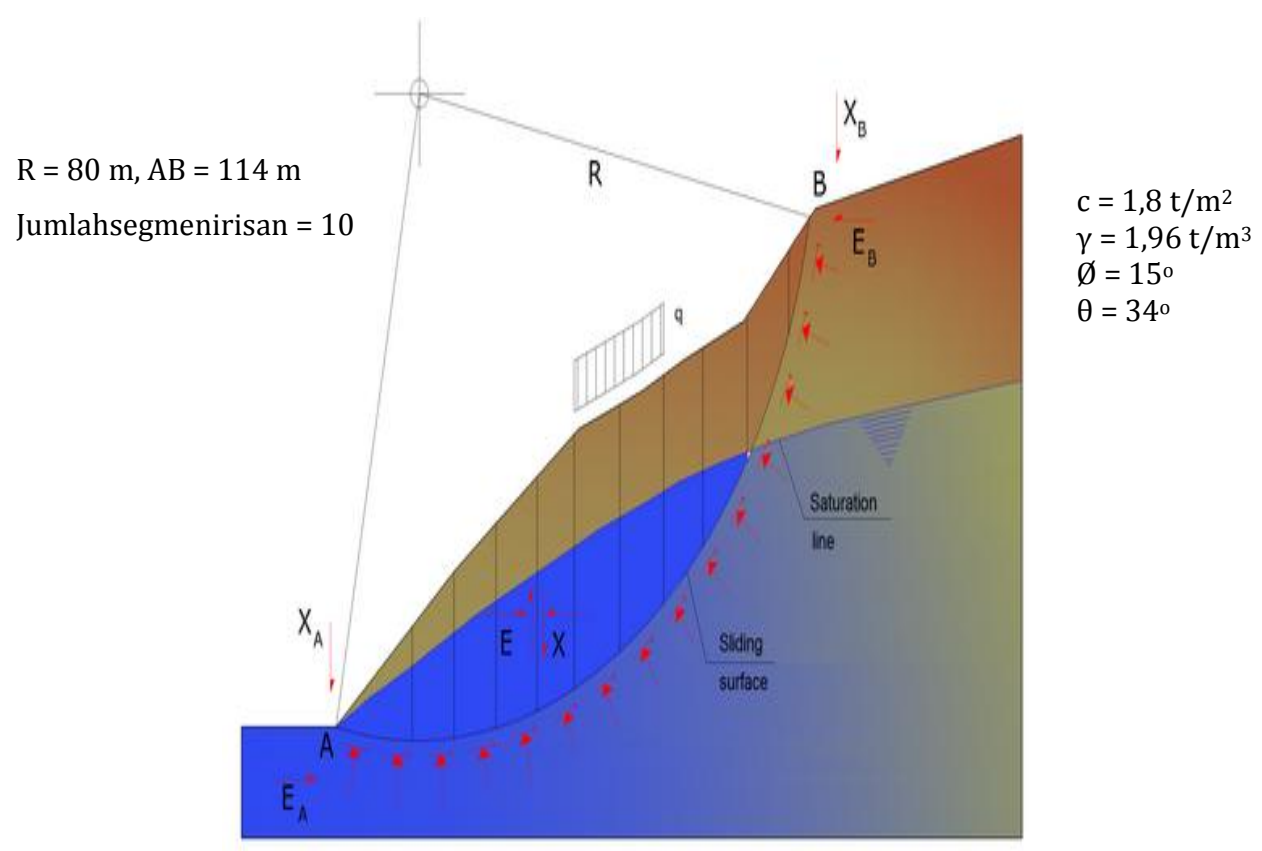

Figure3.1. The slope in Water Treatment Plant and water reservoir in Bikat Permai - Roban

\subsection{The Possible Risk}

\section{A. Cut and Fill in Water Treatment Plant (WTP) and Reservoir}

Volume $\pm 25.410 \mathrm{~m}^{3}$ with $\gamma=1,8 \mathrm{t} / \mathrm{m}^{3}$,

$\mathrm{W}=45738$ ton, $\mathrm{SF}=\mathrm{W} \operatorname{Cos} \theta_{\mathrm{i}}-\mathrm{U}_{\mathrm{i}} / \mathrm{W} \operatorname{Sin} \theta_{\mathrm{i}}$

Cohesion $(\mathrm{c})=1,6 \mathrm{t} / \mathrm{m}^{2}, \theta=1-2^{\circ}$,

The length of landslide field $66 \mathrm{~m}$

Landslide resistance $=\sum$ ci. $a i=1,6 \times 66=105$ ton

$\mathrm{SF}=\frac{c L+\tan \emptyset \sum W i \operatorname{Cos} \alpha i-U i l i}{\sum(W i \operatorname{Sin} \alpha i}$

$\mathrm{W} \operatorname{Cos} \theta_{\mathrm{i}}=45.738 \times \cos 2^{\circ}=45.710$ ton

$\mathrm{U}_{\mathrm{i}}=3630 \times 4 \times 1=14.520$ ton

$\mathrm{W} \operatorname{Sin} \theta_{\mathrm{i}}=45.738 \mathrm{x} \sin 2^{\circ}=1.596$ ton

$\mathrm{SF}=\frac{106+(45.738-14490)}{1596}=16,5>1$, indicating stable

Thus in cut and fill area (WTP and reservoir), structurally it is stable. It is only required to install piling for foundation, based on hard soil sondir at $3.4 \mathrm{~m}$ from surface of $\mathrm{S}-1$ at the direction kit area. At this point, the piling is already penetrating landslide field (refer to Fig. 2.7).

\section{B. Block A (on the upper side of landslide field) with the area of $9,350 \mathrm{~m}^{2}$}

The landslide potency at the upper side area $(55 \mathrm{~m}$ x $170 \mathrm{~m})$ with the thickness of $7 \mathrm{~m}$, hence:

$\mathrm{W}$ (Potency to landslide) $=65.450 \mathrm{~m}^{3}, \theta=35^{\circ}-38^{\circ}, \gamma=1,8 \mathrm{t} / \mathrm{m}^{3}$, with the length of landslide field is $170 \mathrm{~m}$.

Landslide resistance $=\sum c i . a i=1,6 \times 170=256$ ton

Thus $\mathrm{W}=117.810$ ton

$\mathrm{W} \operatorname{Cos} \theta_{\mathrm{i}}=117.810 \mathrm{x} \cos 38^{\circ}=87.977$ ton

$\mathrm{U}_{\mathrm{i}}=9350 \times 5,5 \times 1=51.425$ ton 
$\mathrm{W} \operatorname{Sin} \theta_{\mathrm{i}}=117.810 \mathrm{x} \sin 38^{\circ}=68.850$ ton

$\mathrm{SF}=\frac{256+(87.977-51.425)}{68850}=0,55<1$, indicatingunstable.

\section{Block B (block below landslide field), with the area of $6,600 \mathrm{~m}^{2}$}

Landslide potency at the upper side area $(55 \mathrm{~m} \times 160 \mathrm{~m})$ with the thickness of $6 \mathrm{~m}$, hence

$\mathrm{W}$ (Potency to landslide) $=39.600 \mathrm{~m}^{3}, \theta=34^{\circ}-38^{\circ}, \gamma=1,8 \mathrm{t} / \mathrm{m}^{3}$, with the length of landslide field is $160 \mathrm{~m}$.

Landslide resistance $=\sum c i . a i=1,6 \times 160=256$ ton

Thus $\mathrm{W}=71.280$ ton

$\mathrm{W} \operatorname{Cos} \theta_{\mathrm{i}}=71.280 \mathrm{x} \cos 35^{\circ}=58.543$ ton

$\mathrm{U}_{\mathrm{i}}=6600 \times 4,5 \times 1=29.700$ ton

$\mathrm{W} \operatorname{Sin} \theta_{\mathrm{i}}=71.280 \mathrm{x} \sin 35^{\circ}=41.035$ ton

$\mathrm{SF}=\frac{256+(58.543-29700)}{41035}=0,71<1$, indicatingunstable

\section{Block danger for landslide at the upper side of danger zone with the area of $79,818 \mathrm{~m}^{2}$}

Landslide potency at this area $\left(79,818 \mathrm{~m}^{2}\right)$ with the thickness of $5 \mathrm{~m}$, hence:

$\mathrm{W}$ (Potency to landslide $)=399.090 \mathrm{~m}^{3}, \theta=30^{\circ}-35^{\circ}, \gamma=1,8 \mathrm{t} / \mathrm{m}^{3}$, with the length of landslide field is $200 \mathrm{~m}$.

Landslide resistance $=\sum c i . a i=1,6 \times 200=320$ ton

Thus $\mathrm{W}=718.362$ ton

$\mathrm{W} \operatorname{Cos} \theta_{\mathrm{i}}=718.362 \times \cos 30^{\circ}=622.119$ ton

$\mathrm{U}_{\mathrm{i}}=79818 \times 4,5 \times 1=323.629$ ton

$\mathrm{W} \operatorname{Sin} \theta_{\mathrm{i}}=718.362 \times \sin 30^{\circ}=359.181$ ton

$\mathrm{SF}=\frac{320+(622.119-323.629)}{359181}=0,83<1$, indicating unstable

\section{CONCLUSIONS}

From analytical calculation and geoelectric interpretation, it is concluded that:

1. In general, the cliff of Bukit Permai from $18 \mathrm{~m}$ to 120 above sea level, under raining condition and the ground water level close to the surface, is not safe with $\mathrm{SF}=0,80<1$ (which is indicating unstable condition). Under dry condition, and level of ground water close to lower side of the slope, it is relatively safe, with $\mathrm{SF}=1,08$. The slope will stable if $\mathrm{SF}>1,25$ (safe situation).

2. Based on analytical calculation for each block, it is indicating that WTP site plan and reservoir will be safe for cut and fill, since the slope has $\mathrm{SF}=16,5>1,25$ (indicating very stable condition). The foundation with bored piling is required to prevent soil settlement/subsiding. The piling must penetrating landslide line. And to secure the structure, it is necessary to provide drainage for site area.

3. However, Block A and B, which are situated above the site plan of WTP and reservoir are not safe. The Safety Factors (SF) are $0.55,0.71$, and 0.83 respectively. These are obvious indication that the slope is not safe. Landslide prevention could be done by reducing soil load on the upper side of the slope (trapping/terracing).

4. Other efforts are including drying the ground water at upstream together with strengthening the turap (flowing wall) into the left and right sides of the WTP site plan and reservoir. All of these efforts are the since landslide possibly moves toward the WTP and reservoir infrastructures due to the cliff angle, which is on the direction from north east to south west. 


\section{REFERENCES}

[1] Bishop, A.W. (1955), "The Use of the Slip Circle in the Stability Analysis of Slopes", Geotechnique, Vol. 5, pp. 7-17.

[2] Chowdhury, R. N., 1981. Discussion of "Stability Analysis of Embankments and Slopes," by S. K. Sarma, journal of the Geotechnical Engineering Division, ASCE, Vol.107, No.GT-5, May, pp.691-693.

[3] Chugh, A.K. (1981), Discussion: "Stability Analysis of Embankments and Slopes"by Sarma S.K. American Society of Civil Engginering, Journal of the Geotecnical Engineering Division, Vol. 107, No. GT5, pp. 693-697.

[4] Muchlis. (2015). Interpretasi Potensi Massa Longsoran Dengan Metoda Geolistrik (Studi Kasus Daerah Gayo Lues). Jurnal Natural, 15(1), 16-18.

[5] Pusat Vulkanologi dan Mitigasi Bencana Geologi. (2015). Prakiraan Wilayah Potensi Terjadi Gerakan Tanah/Tanah Longsor dan Banjdengan

[6] Schlumberger, C., M. Schlumberger, and E.G. Leonardon, 1934. Electrical exploration of water-covered areas. Trans. Am. Inst. Mining Metall. Eng., 110, 122-134.

[7] Suriadi, A. B., Arsjad, M. dan Hartini, S. (2014). Analisis Potensi Risiko Tanah Longsor Kabupaten Ciamis dan Kota Banjar, Jawa Barat. Majalah Ilmiah Globe, 16, 165-172. Bandang di Seluruh Indonesia. Bandung: ESDM, Kementrerian

Citation: Nurmaya Putri Ira et al. (2018). The Mitigation of Landslide Disaster at the Area that Formerly a Soil and Rock Mining in Bukit Permai Singkawang, International Journal of Mining Science (IJMS), 4(1), pp.1-10, DOI: http://dx.doi.org/ 10.20431/2454-9460.0401001.

Copyright: () 2018 Nurmaya Putri Ira. This is an open-access article distributed under the terms of the Creative Commons Attribution License, which permits unrestricted use, distribution, and reproduction in any medium, provided the original author and source are credited 